\title{
Deteksi Residu Antibiotik Pada Hati Ayam Broiler Di Pasar Tradisional Kota Mataram
}

\section{Detection Of Antibiotic Residue On The Chicken Broiler's Liver In The Traditional Market Of Mataram}

\author{
Difa Suci Latifah ${ }^{1 *}$, Kunti Tirtasari ${ }^{2}$, Candra Dwi Atma ${ }^{3}$, Alfiana Laili Dwi Agustin ${ }^{4}$ \\ ${ }^{1}$ Asisten Laboran Kesehatan Masyarakat Veteriner UPT Banyumulek, ${ }^{2}$ Dosen Divisi \\ Kesehatan Masyarakat Veteriner, ${ }^{3}$ Dosen Divisi Mikrobiologi dan Parasitologi, ${ }^{4)}$ Dosen Divisi \\ Kesehatan Masyarakat Veteriner \\ Universitas Pendidikan Mandalika \\ *Corresponding author: divasuci@gmail.com
}

\begin{abstract}
Abstrak
Hati merupakan organ yang berperan untuk sekresi empedu, detoksifikasi atau degradasi zat sisa hormon serta obat atau senyawa asing lainnya. Hati ayam broiler disukai oleh berbagai kalangan karena di dalam hati ayam terdapat zat gizi yang penting diantaranya protein $19,70 \%$, lemak 3,20\%, dan air $69,70 \%$. Keamanan bahan pangan mempengaruhi kesadaran masyarakat akan keberadaan pangan asal hewani harus aman dan bebas dari residu antibiotik yang dapat mengganggu kesehatan tubuh. Tujuan dari penelitian ini adalah untuk mendeteksi adanya residu antibiotik pada hati ayam broiler di pasar tradisional Kota Mataram. Penelitian ini menggunakan total sampel 10 hati ayam yang diambil secara random dari 24 penjual ayam broiler di pasar tradisional dengan menggunakan uji tapis. Hasil dari penelitian menunjukkan bahwa pada hati ayam broiler tidak terdeteksi residu antibiotik dari pasar tradisional.
\end{abstract}

Kata kunci: hati, ayam broiler, residu antibiotik

\begin{abstract}
The liver is an organ that play a role in the secretion of gall, detoxification or degradation of hormone resizing and other fireign substances and compounds. Broiler liver is popular in many communities because inside the chicken's liver contains essential nutrients among $19,70 \%$ protein, 3,20\% fat, and $69,70 \%$ water. Food security affects people's awareness of the existence of food stuffs from animal should be safe and free from the residues of antibiotics that could harm the body. The study used a total of 10 samples randomly taken from 24 broiler sellers at the traditional. As a result of this study, broiler's liver is undetectable in antibiotic residue from the tradisional market.
\end{abstract}

Keywords: Hepar, broiler chicken, antibiotic residue

\section{Pendahuluan}

Antibiotik masih digunakan sebagai obat pada ternak. Dosis yang ditetapkan harus sesuai karena banyaknya bahaya residu antibiotik pada produk asal hewani. Residu antibiotik pada ternak unggas perlu diketahui untuk meningkatkan kesadaran peternak dan konsumen akan bahayanya residu antibiotik (Masrianto et al. 2019). Tidak adanya antibiotik pada produk asal hewan menurut Aziz (2021) dimungkinkan karena waktu henti obat sudah tercapai dan dosis sudah sesuai. Hati ayam broiler banyak disukai oleh berbagai kalangan karena di dalam hati ayam terdapat zat gizi yang penting diantaranya protein $19,70 \%$, lemak $3,20 \%$, dan air $69,70 \%$. Hati ayam 
mengandung mineral yang terdiri dari zat besi, kalium, magnesium, fosfor, tembaga dan seng (Depkes RI, 1996). Apabila dalam makanan yang akan dikonsumsi oleh masyarakat mengandung residu antibiotik yang melebihi batas dapat mengakibatkan reaksi alergi, mengganggu mikrofloral saluran pencernaan, gangguan sistem syarafbahkan dapat menimbulkan resistensi terhadap manusia yang mengkonsumsinya (Agustin, 2017).

Marlina et al.(2015) menunjukkan bahwa 13 dari 48 sampel daging dan hati ayam di Kecamatan Pamijahan, Kabupaten Bogor, Jawa Barat positif mengandung residu antibiotik golongan makrolida dan tetrasiklin. Sampel hati yang positif makrolida mencapai 45,83\% (11 dari 24 sampel hati). Sampel yang positif tetrasiklin meliputi sampel hati 4,17\% (1 dari 24 sampel hati) dan sampel daging paha $4,17 \%$ (1 dari 24 sampel daging paha).

Menurut Iyo (2015), peternak memiliki kecenderungan lebih mengutamakan keselamatan ayam dari serangan penyakit dibandingkan pertimbangan residu obat antibiotik pada ayam. Residu dapat ditemukan akibat penggunaan obat-obatan, termasuk antibiotik, pemberian feed additive ataupun hormon pemacu pertumbuhan hewan. Dampak yang ditimbulkan dari adanya residu dalam pangan asal hewan menyebabkan kerugian ekonomi berupa penolakan produk terutama bila produk tersebut di ekspor ke negara yang konsisten dan serius dalam menerapkan sistem keamanan pangan (Iskandar dkk, 2020).

Penggunaan antibiotik yang kurang memperhatikan aturan pemberiannya atau penggunaan antibiotik sebagai pengobatan yang tidak sesuai dengan petunjuk, misalnya waktu henti obat tidak dipatuhi menjelang hewan akan dipotong, akan menyebabkan obat tertinggal di dalam jaringan atau organ tubuh, disebut sebagai residu, yang kemudian akan terakumulasi dengan konsentrasi yang bervariasi.
Pengamatan di lapangan menunjukkan pemakaian antibiotik pada peternak ayam pedaging dan petelur cenderung berlebihan dan kurang tepat, tanpa memperhatikan aturan pemakaian yang benar (Bahri dkk., 2000).

\section{Materi dan Metode}

Penelitian ini merupakan jenis penelitian yang dilakukan dengan kegiatan untuk menyimpulkan suatu masalah dengan melihat, mengamati, mendeskripsikan atau menggambarkan suatu obyek (Penelitian deskriptif). Metode yang digunakan yaitu metode observasional analitik dengan rancangan Cross Sectional yaitu penelitian yang dikumpulkan atau diukur dalam satu waktu atau waktu yang bersamaan dan hanya satu kali (Notoatmodjo. 2012). Penelitian ini akan mendeskripsikan residu antibiotik Oksitetrasiklin pada hati ayam broiler di pasar tradisional Mataram dengan menggunakan Uji Tapis (Screening Test).

Sampel hati ayam broiler diperoleh dari pasar tradisional dengan besaran sample 10 sampel hati ayam dari 24 pedagang yang menjual ayam broiler secara random. Penelitian dilaksanakan pada bulan Februari-Maret 2021. Tempat penelitian dilakukan di Balai Rumah Sakit Hewan dan Laboratorium Veteriner Dinas Peternakan dan Kesehatan Hewan Provinsi NTB.

\section{Alat dan Bahan Penelitian}

Alat yang digunakan adalah coolbox, plastik klip, es gel, pengocok tabung, tiga jenis inkubator $\left(30{ }^{\circ} \mathrm{C} \pm 1{ }^{\circ} \mathrm{C}\right.$, $36{ }^{\circ} \mathrm{C} \pm 1{ }^{\circ} \mathrm{C}$ dan $55{ }^{\circ} \mathrm{C} \pm 1{ }^{\circ} \mathrm{C}$ ), sentrifus $3000 \mathrm{rpm}$, penangas air, lemari steril (clean bench), Homogenizer/Ultrasonic homogenizer, autoklaf, lemari pendingin (refrigerator), Freezer, timbangan analitik, magnet pengaduk, ph meter, pinset, gunting, ose , burner, pipet mikro $50 \mu \mathrm{l}-$ $300 \mu \mathrm{l}$, cawan petri $100 \times 12 \mathrm{~mm}$, tabung reaksi, tabung sentrifus, tabu ukur, gelas ukur, erlenmeyer, botol timbang ukuran 20 $\mathrm{ml}$, pipet volumetrik, pipet graduasi, botol media (roux's bottle). 
Bahan-bahan yang digunakan dalam penelitian ini yaitu: media agar, larutan buffer (KH2PO4, Na2HPO4, H3PO4, NaOH, K2HPO4, $\mathrm{HCl}, \mathrm{NaCl}$ ), mikroorganisme (spora Bacillus stearothermophilus ATCC 7953, spora Bacillus cereus ATCC 11778, spora Bacillus subtillis ATCC 6633, vegetatif Kocuria rizophila ATCC 9341), larutan baku pembanding (natrium penisilin, oksitetrasiklin hidroklorida, kanamisin sulfat, tilosin-tartrat), dan kertas cakram (SNI No. 7424:2008).

\section{Pengambilan Sampel}

Pengambilan sampel dilakukan dengan mengambil satu sampel hati ayam dari masing-masing penjual ayam broiler. Hati ayam kemudian dimasukkan ke dalam klip plastik sampel sebanyak kurang lebih 10 gram. Plastik klip kemudian diberi label dengan sampel satu sampai sampel sepuluh. Sampel tersebut kemudian dimasukkan ke dalam cool box dan dibawa ke laboratorium untuk dilakukan pemeriksaan lebih lanjut.

\section{Pembuatan Larutan Dapar/Bahan Kimia}

Larutan dapar fosfat nomor satu dibuat dengan menimbang 7 gram KH2PO4 dan 6 gram Na2HPO4 yang dilarutkan dalam aquabides sampai 1.000 $\mathrm{mL}$, dengan mengatur $\mathrm{pH}$ hingga menjadi $6,0 \pm 0,1$, lalu di sterilisasi menggunakan autoklaf pada suhu $121 \pm 1{ }^{\circ} \mathrm{C}$, selama 15 menit.

Larutan dapar fosfat nomor dua dibuat dengan menimbang 6,4 gram $\mathrm{KH} 2 \mathrm{PO} 4$ dan 18,9 gram Na2HPO4 yang dilarutkan dalam aquabides sampai 1.000 $\mathrm{mL}$, dengan mengatur $\mathrm{pH}$ hingga menjadi $7,0 \pm 0,1$ kemudian disterilisasi dengan autoklaf pada suhu $121 \pm 1{ }^{\circ} \mathrm{C}$ dengan tekanan Psi atau $1.03421 \times 105$ pascal selama 15 menit.

Larutan dapar fosfat nomor tiga dibuat dengan menimbang 3,5 gram KH2PO4 dan 3 gram Na2HPO4 yang dilarutkan dalam aquabides sampai 1.000 $\mathrm{mL}$, dengan mengatur $\mathrm{pH}$ hingga menjadi $6,0 \pm 0,1$ kemudian di sterilisasi dengan autoklaf pada suhu $121 \pm 1{ }^{\circ} \mathrm{C}$, dengan tekanan 15 psi atau $1.03421 \times 105$ pascal selama 15 menit.

\section{Pembuatan Media}

Pembuatan media biakan Bacillus stearothermophilus untuk pengujian antibiotik golongan penisilin dilakukan dengan menimbang peptone 5 gram, yeast extract 12 gram, bacto agar 15 gram, dextrose 1 gram dan akuabides $1.000 \mathrm{~mL}$. Peptone, dextrose, dan yeast extract dilarutkan dalam sebagian akuabides, setelah tercampur rata ditambahkan bacto agar dan ditambahkan akuabides hingga volume keseluruhan menjadi $1.000 \mathrm{~mL}$. Derajat keasaman disesuaikan pada $\mathrm{pH}$ $5,7 \pm 0,1$ dan dididihkan agar terlarut (SNI No. 7424:2008).

Media biakan Bacillus subtilis untuk pengujian antibiotik golongan aminoglikosida dibuat dengan menimbang peptone 5 gram, beef extract 3 gram, bacto agar 15 gram dan akuabides $1.000 \mathrm{~mL}$. Peptone dan beef extract dilarutkan dalam sebagian akuabides kemudian ditambahkan bacto agar, selanjutnya ditambahkan akuabides hingga volume keseluruhan menjadi $1.000 \mathrm{~mL}$. Derajat keasaman disesuaikan pada $\mathrm{pH} 8,5 \pm 0,1$ dan dididihkan agar terlarut (SNI No. 7424:2008).

Media biakan Bacillus cereus untuk pengujian antibiotik golongan tetrasiklin dibuat dengan menimbang peptone 6 gram, beef extract 1,5 gram, yeast extract 3 gram, KH2PO4 1,35 gram, bacto agar 15 gram dan akuabides 1.000 $\mathrm{mL}$. Peptone, beef extract, yeast extract dan $\mathrm{KH} 2 \mathrm{PO} 4$ dilarutkan dalam sebagian akuabides, kemudian ditambahkan bacto agar, selanjutnya ditambahkan akuabides hingga volume menjadi $1.000 \mathrm{~mL}$. Derajat keasaman disesuaikan pada $\mathrm{pH} 5,7 \pm 0,1$ dan dididihkan agar terlarut (SNI No. 7424:2008).

Media biakan Micrococcus luteus (Kocuria rizophila) untuk pengujian antibiotik golongan makrolida dibuat dengan menimbang peptone 6 gram, beef extract 1,5 gram, yeast extract 3 gram, 
glucose 1 gram, bacto agar 15 gram, dan akuabides $1.000 \mathrm{~mL}$. Peptone, beef extract, yeast extract dan glucose dilarutkan dalam sebagian akuabides, kemudian ditambahkan bacto agar, selanjutnya ditambahkan akuabides hingga volume menjadi $1.000 \mathrm{~mL}$. Derajat keasaman disesuaikan pada $\mathrm{pH} 8,5 \pm 0,1$ dan dididihkan agar terlarut (SNI No. 7424:2008).

\section{Pembuatan Larutan Stok Baku Pembanding}

Penimbangan perlu diperhitungkan potensi dari masing-masing standar yang tertera pada label. Pembuatan larutan baku pembanding penisilin dilakukan dengan menimbang sejumlah baku penisilin $G$ kemudian dilarutkan dalam dapar nomor satu hingga didapatkan konsentrasi 1.000 IU/mL. Larutan baku pembanding oksitetrasiklin dibuat dengan menimbang sejumlah baku pembanding oksitetrasiklin hidroklorida kemudian dilarutkan dalam akuabides hingga diperoleh konsentrasi $1.000 \mu \mathrm{g} / \mathrm{mL}$. Pembuatan larutan baku pembanding kanamisin dilakukan dengan menimbang sejumlah baku pembanding kanamisin sulfat kemudian dilarutkan dalam dapar nomor 3 hingga diperoleh konsentrasi $1.000 \mu \mathrm{g} / \mathrm{mL}$. Larutan baku pembanding tilosin dibuat dengan menimbang sejumlah baku pembanding tilosin tartrat dilarutkan $10 \%$ methanol dalam akuabides hingga diperoleh konsentrasi $1.000 \mu \mathrm{g} / \mathrm{mL}$.

\section{Analisis Data}

Data yang diperoleh dianalisis sesuai dengan uji tapis yaitu dengan cara menyatakan hasil dengan mengamati dan mengukur diameter daerah hambatan yang terbentuk disekeliling kertas cakram dengan menggunakan alat ukur yang sesuai. Kontrol positif harus membentuk daerah hambatan dari tepi kertas cakram. Kontrol negatif harus tidak membentuk daerah hambatan.

\section{Hasil dan Pembahasan}

Berdasarkan pengujian residu antibiotik pada 10 sampel hati ayam broiler dengan menggunakan metode Uji Tapis (Screening Test) yang berasal dari pasar tradisional Kebon Roek menunjukkan hasil negatif mengandung residu antibiotik oksitetrasiklin. Hasil negatif pada sampel ditandai dengan tidak terbentuknya zona hambat di sekitar kertas cakram yang mengandung sampel hati ayam broiler.

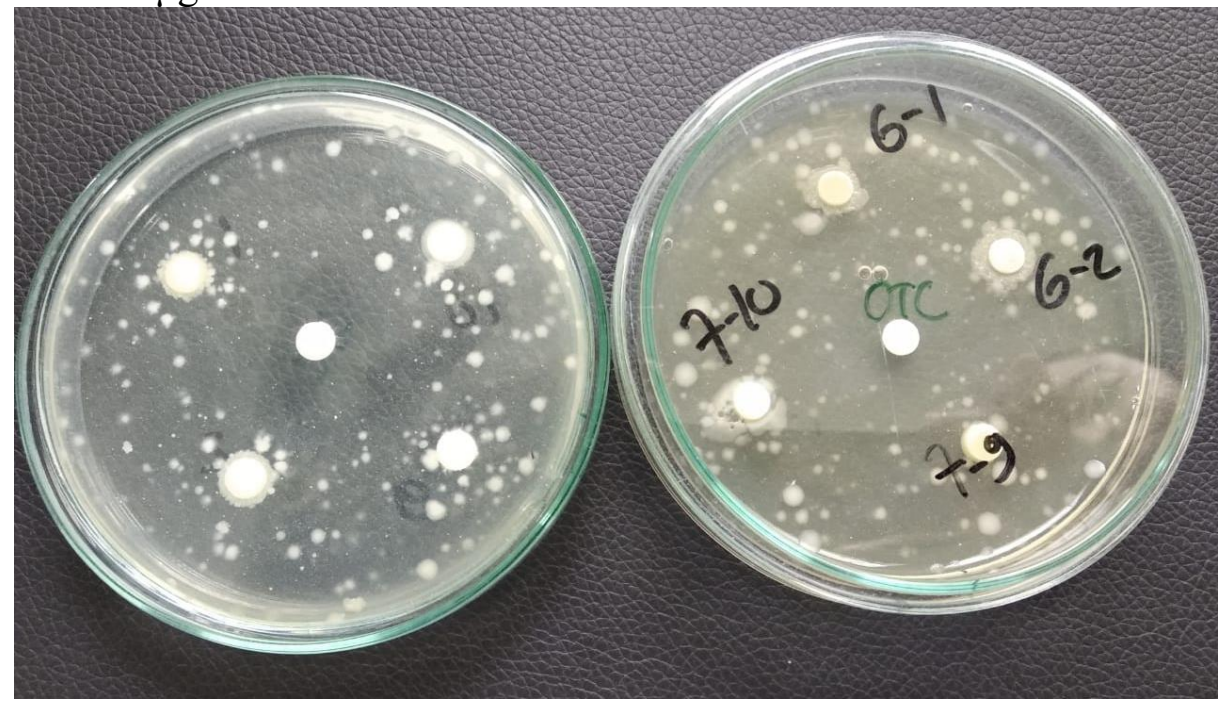

Gambar 1 Hasil Pengujian sampel untuk mendeteksi residu antibiotik terlihat tidak adanya zona yang terbentuk

Hasil pengujian residu antibiotik dari 10 sampel hati ayam broiler yang berasal dari pasar tradisional Kebon Roek dengan menggunakan metode uji tapis (Screening Test) dapat dilihat pada tabel 1:

Tabel 1 Hasil Pengujian Residu Antibiotik 


\begin{tabular}{|c|c|c|c|c|c|}
\hline \multirow{2}{*}{$\begin{array}{l}\mathrm{N} \\
\mathrm{O}\end{array}$} & \multirow{2}{*}{$\begin{array}{c}\text { Kode } \\
\text { Samp } \\
\text { el }\end{array}$} & \multicolumn{4}{|c|}{$\begin{array}{c}\text { Hasil Pengujian Residu } \\
\text { Antibiotik }\end{array}$} \\
\hline & & $\begin{array}{c}\text { ML' } \\
\text { s }\end{array}$ & $\begin{array}{c}\mathrm{AG}^{\prime} \\
\mathrm{s}\end{array}$ & $\begin{array}{c}\mathrm{TC}^{\prime} \\
\mathrm{s}\end{array}$ & $\begin{array}{c}\mathrm{PC}^{\prime} \\
\mathrm{S}\end{array}$ \\
\hline 1 & $\begin{array}{l}00006 \\
-1\end{array}$ & - & - & - & - \\
\hline 2 & $\begin{array}{l}00006 \\
-2\end{array}$ & - & - & - & - \\
\hline 3 & $\begin{array}{l}00006 \\
-3\end{array}$ & - & - & - & - \\
\hline 4 & $\begin{array}{l}00006 \\
-4\end{array}$ & - & - & - & - \\
\hline 5 & $\begin{array}{l}00006 \\
-5\end{array}$ & - & - & - & - \\
\hline 6 & $\begin{array}{l}00006 \\
-6\end{array}$ & - & - & - & - \\
\hline 7 & $\begin{array}{l}00006 \\
-7\end{array}$ & - & - & - & - \\
\hline 8 & $\begin{array}{l}00006 \\
-8\end{array}$ & - & - & - & - \\
\hline 9 & $\begin{array}{l}00006 \\
-9\end{array}$ & - & - & - & - \\
\hline 10 & $\begin{array}{l}00006 \\
-10\end{array}$ & - & - & - & - \\
\hline
\end{tabular}

Keterangan:

$\begin{array}{ll}\text { ML's } & \text { : Makrolida } \\ \text { AG's } & \text { : Aminoglikosida } \\ \text { TC's } & \text { : Tetrasiklin } \\ \text { PC's } & \text { : Penicilin }\end{array}$

Faktor yang menyebabkan hasil pengujian residu negatif yaitu (1). Waktu pemelihaaraan ayam broiler yang singkat sehingga menyebabkan tidak terdapatnya residu antibiotik. (2). Penggunaan antibiotik yang sesuai dengan dosis yang dianjurkan. (3). Peternakan yang sudah memperhatikan waktu henti obat (withdrawal time). Waktu henti obat (withdrawal time) adalah kurun waktu dari saat pemberian obat terakhir sampai ayam diperbolehkan untuk dipotong atau produknya dapat dikonsumsi, ini merupakan waktu yang cukup sampai konsentrasi obat dalam tubuh hewan menurun sampai batas toleransi. Antibiotik jenis oksitetrasiklin memiliki waktu henti obat selama 15 hari. Penelitian yang dilakukan oleh Sanjaya (2016) yang menunjukkan bahwa antibiotik dapat ditemukan pada hasil ternak jika hasil ternak tersebut dipanen sebelum masa waktu henti obat (withdrawal time) habis pada hewan yang diobati atau karena antibiotik dalam pakan. Waktu henti obat hewan sangat bervariasi, bergantung pada: 1) jenis obat, 2) spesies hewan, 3) faktor genetik ternak, 4) iklim setempat, 5) cara pemberian, 6) dosis obat, 7) status kesehatan hewan, 8) produk ternak yang dihasilkan, 9) batas toleransi residu obat, dan 10) formulasi obat (Infovet, 2007). Faktanya bahwa oksitetrasiklin yang diformulasikan secara long-acting diformulasikan untuk bertindak lebih lama dengan mengurangi laju pelepasan dan penyerapan dari lokasi pemberian. Formulasi secara long-acting dapat menambah waktu withdrawal time oksitetrasiklin. Tidak ditemukannya antibiotik oksitetrasiklin bukan berarti tidak ada antibiotik jenis lain (Agustin, 2017).

\section{Kesimpulan}

Hasil penelitian terhadap residu antibiotik dengan metode uji tapis (Sreening Test) pada 10 sampel hati ayam broiler yang diambil di pasar tradisional Kebon Roek Kota Mataram menunjukkan hasil negatif yang berarti tidak mengandung residu antibiotik.

\section{Ucapan Terima Kasih}

Terima kasih kepada kepala UPTD Rumah Sakit Hewan dan Laboratorium Veteriner yang telah memberikan kesempatan kepada penulis untuk kelancaran penelitian ini.

\section{Daftar Pustaka}

Agustin, A. L. D. (2017). Tingkat cemaran bakteri dan deteksi residu antibiotik pada telur ayam layer dari peternakan Gemas Kabupaten Lombok Utara. Jurnal Sangkareang Mataram, 3(3), 3335.

Aziz, A., Agustin, A. L. D., \& Atma, C. D. (2021). Deteksi Residu Antibiotik 
Pada Telur Ayam Layer Di Peternakan Ayam Layer Di Sesaot Lombok Barat. Vitek: Bidang Kedokteran Hewan, 11(1), 48-52.

Bahri, S., Kusumaningsih, A., Murdiati, T. B., Nurhadi, A., dan Masbulan, E. 2000. Analisis Kebijakan Keamanan Pangan asal ternak (Terutama Ayam Ras Petelur dan Broiler). Laporan Penelitian Bogor:Pusat Penelitian dan Pengembangan Peternakan.

Brander G., D. Pugh, R. Bywater and W. Jenkens. 1991. Veterinary Applied Pharmacolog and Therapeutics, $5^{\text {th }}$ edn., ( Braillere, Tindall, London) 484-488.

Crawford, L dan Franco, D. A. 2014. Animal Drug Residues in Processed Meats -Protential Health Risk. University of Wisconsin

Madison.http://focosi.altervista.or g.

Departemen Kesehatan RI. 1996. Daftar Komposisi Bahan Makanan. Jakarta: Bhratara.

Giguere, Steeve. 2006. Antimicrobial Theraphy in Veterinary Medicine Fourth Edition. Blackwell Publishing.

Infovet, 2007. Peran obat hewan dalam keamanan produk ternak. (http://www.majalahinfovet.com/ 2007/10/peran-obat-hewandalam-keamanan=produk.html).

Iyo. 2015. Peternak, penyakit bakteri dan antibiotika. Majalah Infovet Online.

http://www.majalahinfovet.com/2 007/10/peternak-penyakit-bakteridan.html.

Marlina, N. A., Zubaidah E, Sutrisno A. 2015. Pengaruh pemberian antibiotik saat budidaya terhadap keberadaan residu pada daging dan hati ayam pedaging dari peternakan rakyat. J. Ilmu-Ilmu Peternakan. 25(2): 10-19.
Masrianto, Arief, I. I., dan Taufik, E. 2019. Analisis residu antibiotik serta kualitas daging dan hati ayam broiler di Kabupaten Pidie Jaya Provinsi Aceh. Jurnal Ilmu Produksi Dan Teknologi Hasil Peternakan, 7(3), 102-110. https://doi.org/10.29244/jipt hp.7.3.102-110.

Notoatmodjo, S. 2012. Promosi Kesehatan dan Perilaku Kesehatan. Jakarta:Rineka Cipta.

Sanjaya , A. W. 2016. Bahan dan Antibiotik di dalam Susu. Makalah disampaikan pada Kursus Singkat Pengendalian Mutu dalam Industri Susu. Fakultas Kedokteran Hewan IPB, Bogor.

Standar Nasional Indonesia (SNI). 2000. Batas Maksimum Cemaran Mikroba dan Batas Maksimum Residu dalam Bahan Makanan Asal Hewan. SNI 01- 6366-2000. 